Peer review: This article has been subject to a double blind peer review process

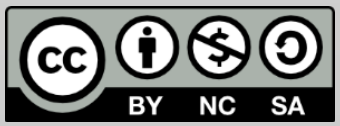

(c) Copyright: The Authors. This article is issued under the terms of the Creative Commons Attribution NonCommercial Share Alike License, which permits use and redistribution of the work provided that the original author and source are credited, the work is not used for commercial purposes and that any derivative works are made available under the same license terms.

\section{Palestinian Refugees: A Gendered Perspective}

\section{Nof Nasser Eddin*}

Centre for Transnational Development and Collaboration, London, UK

*Correspondence: n.nasser-eddin@ctdg.org

\begin{abstract}
This article argues that the situation of Palestinian refugees is still relevant till this day. There are around five million refugees living in neighbouring Arab countries, such as Lebanon, Jordan, Syria and Egypt, as well as neighbouring areas in Palestine itself, like the West Bank and Gaza Strip, under very precarious conditions. Their situation is extremely unstable as any changes in the region can influence them directly.
\end{abstract}

The need to address this issue is particularly important because Palestinian refugees (as well as internally displaced Palestinians) have been both historically and politically marginalised. In particular, I will argue for a need to gender the debate around the Palestinian refugees, because the distinct experience of women Palestinian refugees has been overlooked within this context. Most literature has focused on the Palestinian refugees as a holistic population, which assumes all refugees share the same struggle. However, understanding the position of women within the context of the refugees and the unique struggles they face is essential to understanding their particular experiences as refugees and in highlighting their differential needs; this is why a feminist perspective is needed within the field of refugee studies.

This article is based on a feminist journey drawing on research interviews with female Palestinian refugees in camps in Jordan, and with Syrian Palestinian women in Turkey, Jordan and Europe.

Keywords: Palestine; women refugees; feminism; feminist methodology; Zionism; Palestinian refugee camps

\section{Introduction}

Over the past two years, the issue of Palestinian refugees has come centre stage following the Syrian crisis, which resulted in the siege of alYarmouk refugee camp in Syria, which began in December 2012. The issue of Palestinian refugees in Syria is highlighted by the intensification 
of events in Syria since March 2011, which poses an increased threat to the lives of Palestinian refugees living in camps within these borders.

In this article, I will argue firstly that the issue of Palestinian refugees is still relevant today, despite the fact that sixty-seven years have passed since their expulsion from their homeland, known today as Israel. As Shiblak (1996) argues, Palestinian refugees are the largest single refugee group that has been left in limbo for almost sixty-seven years. The need to address this issue is particularly important because Palestinian refugees (as well as internally displaced Palestinians) have been both historically and politically marginalised.

Secondly, I will argue for a need to gender the debate around the Palestinian refugees, because the distinct experience of women Palestinian refugees has been overlooked within this context. Most literature has focused on the Palestinian refugees as a holistic population, which assumes all refugees share the same struggle. However, understanding the position of women refugees and the unique struggles they continue to face is essential to understanding their particular experiences as refugees and in highlighting their differential needs; this is why a feminist perspective is needed within the field of refugee studies.

This article is based on a feminist journey conducted across different times and spaces. It is based on research interviews with women Palestinian refugees in camps in Jordan, and interviews with Syrian Palestinian women in Turkey, Jordan and Europe. It also utilises secondary data gathered about the overall situation of Palestinian refugees across different host countries. Part of the research data was gathered during my $\mathrm{PhD}$ fieldwork ${ }^{1}$ and another part has been carried out for research conducted by the Centre for Transnational Development and Collaboration. ${ }^{2}$ Utilising a feminist approach to understand the experiences of refugees is important for both epistemological and methodological reasons. Epistemologically, I look at women's experiences as a valid source of knowledge, in addition to looking at the participants as constructors of their 'own realities' rather than passive 'objects' under study (Reinharz, 1992). Moreover, Palestinian women refugees in particular have been marginalised from academic debate, and

\footnotetext{
${ }^{1}$ Undertaken at the University of Warwick between 2007 and 2008, partly funded by Birzeit University and Gender Economic Research and Policy Analysis (GERPA). Research participants were chosen using a snowballing technique so sampling was opportunistic and were asked the same interview questions. For this research, I obtained ethical approval from the University of Warwick to carry out my research.

2 The Centre for Transnational Development and Collaboration carries out research on vulnerable groups across the world. Part of its work has been undertaken among displaced Syrians and Palestinians. The Centre has permitted the use of this data for this publication: www.ctdc.org
} 
a feminist perspective will give this marginalised group a voice. In likeness to feminist theory and methodology, it is important to acknowledge the intersectionality of systems of oppression to understand experiences differently.

\section{Historical Background}

Whereas the Palestinian diaspora started after 1948, its history can be traced back to the history of the region during and before British colonisation of the area. After the fall of the Ottoman Empire in 1918, French and British colonialist powers with the agreement of the Russians signed a secret agreement known as the Sykes-Picot Agreement, to divide the Levant region, located in a large area of southwest Asia, between them (see Map 1). Britain was allocated Palestine, which nowadays constitutes the land occupied by Israeli occupation forces, the West Bank and the Gaza Strip, in addition to Transjordan, which is now known as the Hashemite Kingdom of Jordan (see Map 2).

During this period, both Palestine and Transjordan were under the British Mandate of Palestine. In 1917, the Balfour Declaration was announced, which was in the form of a letter from the UK's foreign secretary Arthur James Balfour to the Zionist federation. The letter stated that Britain was in favour of giving a 'home' for the European and Arab Jews in Palestine. Ever since this promise, Jewish refugees started migrating to Palestine from around the world and began promoting the creation of the Zionist state of 'Israel' on Palestinian land, under the British Mandate of Palestine. This led to the General Assembly of the United Nations to adopt a resolution, which recommended the termination of the British Mandate and the division of the country into two states: one Arab and one Jewish. Therefore, on May 14, 1948, the Zionist entity announced its establishment, one day prior to the end of the British Mandate. 


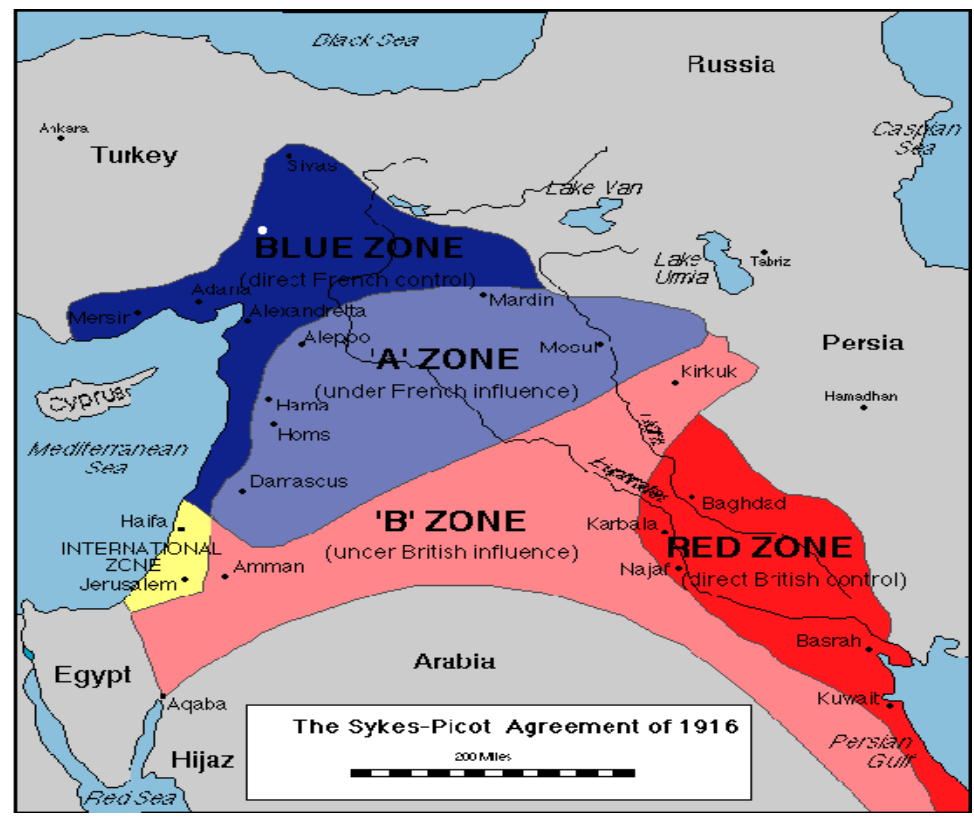

Map 1 Sykes-Picot Agreement

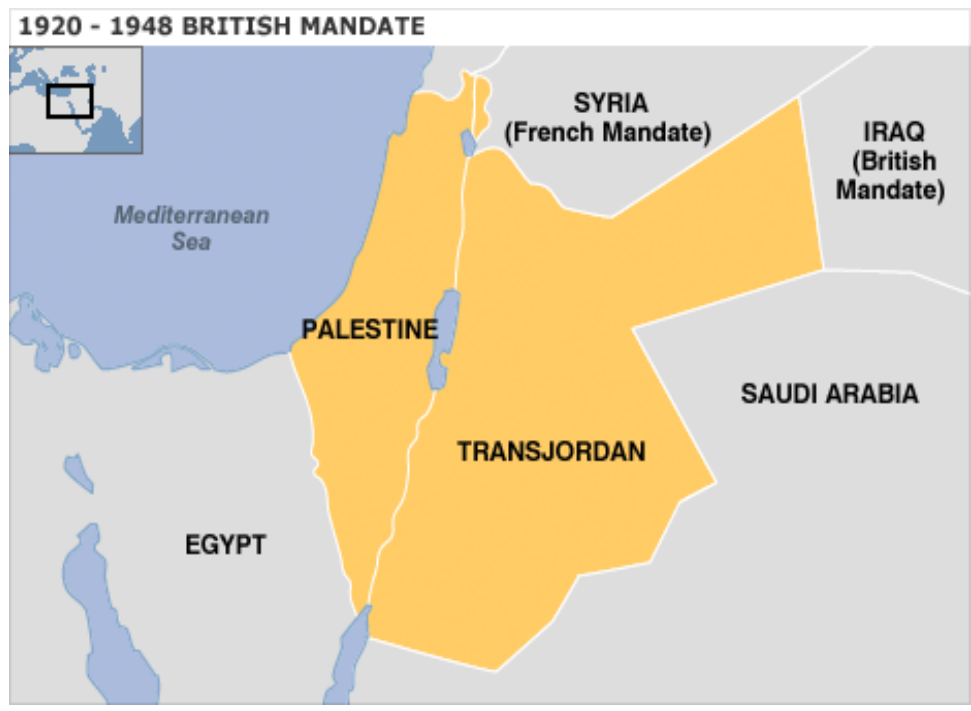

Map 2 British Mandate of Palestine and Transjordan

The issue of Palestinian refugees emerged after the establishment of the Zionist state on Palestinian land in 1948, which resulted in the forced migration of 750,000 Palestinians. The forced migration of Palestinians was called Al-Nakba, meaning 'The Disaster', where individuals were forced to leave their houses, land and property and find refuge in other countries, or in other areas in occupied Palestine (Abu Murad, 2004; Khalidi, 2005; UNHCR, 2000). To respond to the Palestinian refugee issue, the United Nations Relief and Works Agency for Palestine Refugees in the Near East (UNRWA), was established in 1949 by the UN General Assembly, to become the sole relief and dedicated human development agency to provide Palestinian refugees with basic necessities such as 
education, healthcare, social services and emergency aid in the occupied Palestinian territories of the Gaza Strip, West Bank, and neighbouring Arab countries including Jordan, Lebanon and Syria. The UNRWA's first response to Palestinian refugee flows was to provide them with temporary tents, which due to their prolonged diaspora later had to be replaced with more permanent shelters that eventually became permanent refugee camps. It is also worth mentioning that there are Palestinian refugees in Iraq and Egypt, however, they are not officially registered as refugees and thus are not eligible for assistance from the UNRWA.

UNRWA's remit is very limited to the humanitarian aspects of refugees' lives, in other words it explains that UNRWA is only responsible for providing Palestinian refugees with basic needs and relief assistance, and its work does not include helping Palestinians return to their homelands and/or offering compensations for their loss. Ever since the Israeli occupation of Palestine, Palestinian refugees and their descendants have been struggling to attain their right to return, as political compromises and Israel's prevention of their return have so far prevented them from having their demands realised, as Israel wants the Zionist state as an exclusively Jewish state (Akram, 2002; UNHCR, 2000; Ehrlich, 2004).

Those 750,000 displaced individuals have been hosted by neighbouring countries, such as Lebanon, Jordan, Syria and Egypt, as well as neighbouring areas in Palestine itself, like the West Bank and Gaza Strip (Khawaja, 2003). However, the flow of Palestinian refugees did not stop in 1948. On the contrary, more refugees subsequently fled to neighbouring countries; around 300,000 Palestinians were displaced in 1967 due to the Zionist occupation of the whole Palestinian land resulting from the six-day war (Shiblak, 1996). Jordan has the majority of UNRWA registered persons, and the number is estimated at 2,097,300, which leaves 1,258,600,762,300, 480,000 and 450,000 people in the occupied Gaza, occupied West Bank, Syria and Lebanon respectively. It is worth mentioning that most Palestinian refugees and internally displaced persons live outside the camps (Badil, 2015). The total number of Palestinian refugees is estimated at 7.25 million in total; 6.1 million became refugees after the first Zionist occupation, which is known as AlNakba, and 1.113,200 million after the 1967 Zionist occupation. 5.1 million Palestinian refugees are registered with the UNRWA, and around 1.03 million are unregistered refugees (Badil, 2015).

There is a large amount of academic and non-academic writings describing the bad situation of the Palestinian refugees, which treats them as a homogenous community without shedding light on gender, age, or class differences. For instance, El Abed (2006), Elsayed-Ali (2006), 
and Shiblak (2006) among many others have focused on descriptively portraying the living conditions of the refugee population and the discrimination they suffer, without taking differences into consideration. The main difference that has been acknowledged in the secondary literature has been the differences between host countries and their treatment of the refugee population. For example, Palestinian refugees are allowed to seek employment in Jordan, but are not allowed to do so in Lebanon. In Lebanon, the refugee population is provided with a travel document to travel and they are not granted Lebanese citizenship. They also face a big housing problem. There are also official and unofficial camps and UNRWA is responsible for the maintenance of official camps in Lebanon. However, since the 1990s the Lebanese government has prevented any material entering the camps for maintenance purposes. On the other hand, unofficial camp conditions are even worse, since most houses are made of iron and do not offer adequate protection. In short, as El Sayed-Ali states, the camps suffer 'from serious problemsno proper infrastructure, overcrowding, poverty and unemployment' (Elsayed-Ali, 2006: 13).

In Jordan, on the other hand, many Palestinian refugees who resided in Jordan after the 1948 Nakba were granted Jordanian citizenship. Having Jordanian citizenship means that they and their descendants have valid passports for five years, the right to vote and access to governmental services. However, this does not mean that they are treated as 'Jordanians'. As I mentioned earlier, Jordan has the largest number UNRWA registered refugees. The situation of Palestinians in Jordan is therefore very precarious. In theory they should be treated like 'Transjordanians' ${ }^{3}$. However, in reality it is the opposite. Although Palestinians with Jordanian citizenship are allowed to work in the public sector, they face widespread discrimination and the majority therefore seek employment in the private sector. There is also a huge gap between Palestinian refugees living in camps and non-camp refugees, non-refugee Palestinians and Transjordanains.

The struggle of Palestinian refugees has not only been relevant to their flight between 1948 and 1967, but is still very much significant today, because their political status is not equal to that of other refugees around the world. Their positions have not only been influenced by Israel's discriminatory policies, but also by their precarious political, economic and social status in host countries. The issue of Palestinian refugees has been thoroughly studied and analysed by many academics who state that the influx of Palestinian refugees from 1948 is not seen as

\footnotetext{
3 Transjordanians is a term adapted during the British Mandate of Palestine and Transjordan to describe the native inhabitants of what is now known as Jordan.
} 
the outcome of random acts of violence against the Palestinian population, but is depicted as the fruition of a long-standing colonial attitude by the Zionist movement going back to the latter part of the nineteenth century and captured by the slogan, "A land without a people for a people without a land"' (Zureik, 2002: 2; Masalha, 1992; Khalidi, 1992). Yet, as previously mentioned, very little has been said about women refugees and their unique experiences.

\section{Palestinian Refugee Conditions}

Before turning to the particular experiences of Women Palestinian refugees, I want to begin by saying something about the general conditions of the refugee camps, which I will later draw on in teasing out the specific issues faced by women.

In Jordan, those who live in camps are considered the poorest and least educated community; they are the most marginalised and isolated. The camp conditions are poor in terms of infrastructure. In addition to overcrowded conditions and very little employment opportunities, Palestinian refugees who live in camps in Jordan are unable to leave the camps because of high levels of poverty, and low levels of education. In addition, they consider the camps as part of their Palestinian identity, which they want to preserve. For example, during my visit to one Jordanian camp, I learnt that many of these people have retained a very old Palestinian accent, which was transmitted by their ancestors. Staying in the camp also represents their own resistance and resilience and emphasising their 'right of return'. They hope to return to their home country, which was taken away from them in 1948 when the Zionist state was established.

In Lebanon, Palestinian refugees have been considered the poorest group of people in the country and the poorest amongst Palestinian refugees in other countries. Wadie Said criminalises the Lebanese state for marginalising and refusing to accept Palestinian refugees as citizens, especially since the prospect of their return is 'as remote as ever'. Palestinian refugees in Lebanon have not only had to tolerate the consequences of war, but have also 'remained confined in hideous quarantine for almost two generations. They have no legal right to work in at least sixty occupations; they are not adequately covered by medical insurance; they cannot travel and return; they are the objects of suspicion and dislike' (E. Said, 2001: 3).

In recent years, the situation in Syria has affected the population of Palestinian refugees in both Syria and Lebanon. As many Palestinians found themselves homeless in Syria, they sought refuge in Lebanon, and 
the Lebanese government confined them to the Palestinian refugee camps, causing even more overcrowding and poverty. Palestinian Syrian refugees are treated differently from Syrian refugees. Syrian refugees, for example, do not need tourist visas to enter Lebanon, whereas SyrianPalestinians do need ID documents, and in some cases entry permits. Additionally, the Lebanese government has stopped renewing the residency of Syrian Palestinian refugees and issued a decree to ban any Palestinian from entering the country.

As one interviewee stated: 'we the Palestinians have become homeless three times. My grandparents have fled the Zionist occupation in 1948, then we had to leave Syria to Lebanon because of the civil war, and in Lebanon we were imprisoned in camps and we were not treated as human beings. So we fled to Turkey' (Palestinian refugee interviewee in Turkey, 2013). Many of these Palestinians who suffer from discrimination in Arab hosting countries had to leave for Europe in boats through dangerous and life threatening routes, many have lost their lives on the way.

\section{Researching the 'untouchables': A Feminist Perspective.}

Research carried out on Palestinian refugees mainly focuses on describing their situation, such as, the refugee camps and access to employment and education, in addition to their positioning in the host countries (Abu Murad, 2004; Khalidi, 2005; UNHCR, 2000). Other studies explore the experiences of Palestinian women refugees in relation to their Palestinian national identity. For example, a study, carried out by Hanafi (2011) in Palestinian refugee camps in Lebanon and Syria, talks about women and their active resilient role in transmitting their own narrative to their children about their homeland (Palestine). He states that women 'enrich male-dominated history-telling with a female tradition' (Hanafi, 2011: 29). Those studies reinforce women's ascribed gender roles as 'reproducers' of the nation and 'bearers of the collective', and in this case the narrative of the Palestinian national identity is the main focus, rather than the experience itself. In other words, using this narrative overlooks women's experiences and the discrimination they face because of their gender, and instead highlights their position within the overall framework of national identity and struggle. Thus women become part of the narration and an extension of the nation, rather than independent entities, who might suffer from forms of oppression, in addition to the occupation.

Moreover, based on research she conducted in 1990 in the West Bank and Gaza Strip, Abdo (1994) discusses the concept of nationalism and 
feminism and how there is a huge difference between state nationalism and the struggle for liberation nationalism. She states that state nationalism is very much oppressive to women as it confines women to the domestic sphere to just reproduce for the nation and create a national identity through child bearing roles. She also states that this kind of nationalism is not only sexist but also racist as it creates racial discrimination (Abdo, 1994). For example, the Zionist state encourages Jewish women to have children to increase the number of Jewish people within its state boundaries. The Zionist state has policies like 'the fund for encouraging birth', which gives housing loans to families with more than three children. On the other hand, the Zionist state has introduced policies, which target Arab women specifically. For example, they have lowered the national insurance benefits for Arab Women and introduced free contraception. She argues that the struggle for liberation nationalism can be equally sexist for the use of certain narratives about women and men and putting pressure on the role of women, however it is characterised by having the 'potential of being emancipatory and progressive' (Abdo, 1994: 151).

I agree with Abdo's argument regarding gendered discrimination when it comes to national identity, either in a state or a movement for the struggle for liberation. However, I disagree with her on the point that the struggle for liberation can be more progressive and emancipatory depending on women's involvement to push their rights at the front. Women's rights are always pushed to the background because they are not seen a 'priority'. Unfortunately, the struggle for liberation has become extremely institutionalised and women's rights have also been pushed away and been very much boxed and framed to work within an agenda. Abdos' article was written in 1990 when things were completely different and much more hopeful. Nowadays the struggle for liberation is only one concern-refugees also have the struggle for liberation from the Zionist occupation and also for liberation from the Palestinian Authority, which is compromising more on the rights of the Palestinians in general and the refugees in particular. This makes it even harder for women to end patriarchal oppression.

Women's roles are really important when it comes to national movements. However, they are always seen as symbols rather than active participants to end colonialism and oppression (Enloe, 1989). Women are used as symbols not only against the coloniser but also in their own community. For example, from one of my interviews, a Palestinian activist and feminist commented: 'Palestinian women nowadays carry a huge burden, their role changes depending on the political context and they become symbols. I know someone whose husband was martyred, two months after their wedding. She was forced 
by her family and her in-laws to wear a full burqa, if she wanted to carry on with her education. Her status has changed, she has become the wife of a martyr, and so she accepted to carry on with her education and wear a full burqa'. The symbolic role that is given to Palestinian women is applicable to all sections of the Palestinian community; it can be practised by women from different classes and statuses, including refugee women living in camps. Also, when women perform their ascribed symbolic gender roles, they are always praised by men and their community for doing their job 'properly'.

Enloe states that: 'The more imminent and coercive the threat posed by an outside power-a foreign force or the local government's police-the more successful men in the community are likely to be in persuading women to keep quiet, to swallow their grievances and their analyses. When a nationalist movement becomes militarised, either on its leaders' initiative or in reaction to external intimidation, male privilege in the community usually becomes more entrenched' (Enloe, 1989: 56). Based on my experience and conversations with women activists, it has become apparent that targeting women's 'issues' is not considered necessary until the Palestinian people get their liberation. Therefore, when women ask for gender equality, their request is crushed because women's 'issues' are perceived as being 'less' important than ending occupation.

Nationalism and national movements have certainly contributed towards women having spaces as national actors. However, those national movements and nationalisms are very patriarchal and still place women in inferior positions. Political oppressions and colonialism have indeed contributed to hindering the development of different aspects of the lives of the colonised and especially women. This is because nationalist narratives are based on the premise that independence and liberation from colonisation is the priority, and following that women's liberation can be pursued.

A feminist approach to Palestinian refugees does the opposite. By focusing on the experience of women from below and through their eyes, I argue that there should be a shift when it comes to talking about Palestinian refugees in Arab neighbouring countries. We should adopt a feminist methodology to unpack the experiences of women refugees and make their voices louder. I suggest that a feminist approach is the most suitable, as it gives a complete picture of these female refugees' experiences. A feminist approach adds a more comprehensive analysis of the situation of refugees to the literature, because it does not only look at their experiences from a political perspective but also from a social and economic perspectives. Shalhoub-Kevorkian in her 2010 article 'Palestinian Women and the Politics of Invisibility: Towards a Feminist 
Methodology' discusses the 'Politics of Invisibility', in which she states that women's voices and experiences are often marginalised when there is war and conflict. She sheds light on the importance of adopting a feminist methodology and involving women, especially under such circumstances, in research, because their knowledge can 'cast light on the unprecedented levels of hegemonic military power that is used tooccupy land, demolish homes, and wage unequal wars between civilians and the state- in this case- the Israeli state' (Shalhoub-Kevorkian, 2010: 1). The context of her study explores Palestinian women's experiences under Israeli colonialism and occupation. This article, by contrast, particularly discusses the experiences of Palestinian refugees in Arab neighbouring countries.

In order to fully understand refugees' situation, one therefore needs to take their experiences thoroughly into account, because personal experiences have to great extent political implications (Stanley and Wise, 1990; Stanley and Wise, 1993; Klein, 1983). Additionally, a feminist approach takes gender into consideration, through looking at how women's experiences are different from men's. We can also see how gender can be used to draw group boundaries within certain communities and, in the case the refugee community, will enable a more complex picture of Palestinian Refugees to emerge. Furthermore, I argue that refugee camp women suffer from more cultural restrictions in comparison to other women because of the camp-specific situation. Taking women's experiences into consideration is not only important because of cultural restrictions and patriarchy, but also important for understanding the broader context in terms of displacement, political violence, and economic exploitation and how that affects women refugees differently.

\section{Women in Refugee Camps}

Whereas countries hosting Palestinian refugees in the region are considered patriarchal, Palestinian refugee women suffer from stricter patriarchal control in camps (El-Solh, 2003; Moghadam, 1993; Kandiyoti, 1988; Joseph, 1993; 1996). For example, Jordan is considered a patriarchal country where it is expected that both men and women will adhere to specific gender roles (Amawi, 2003). I observed during my visits to the camps in the capital of Jordan that the areas are very conservative, and the practise of patriarchy is clearly much more dominant than in other parts of Amman. It has become apparent that people in Palestinian refugee camps have maintained close personal bonds, which can be attributed to the fact that this camp was established in the 1950s, just after the establishment of the Zionist state on 
Palestinian lands. Due to the lack of governmental support and protection, high poverty levels and isolation of the camps from other parts of Jordan created subcultures within Palestinian camps. In other words, there are economic, social and political differences between people living within and outside the camps. This has created particular social and cultural groupings, and in such circumstances gender can be one of the markers for defining group borders. As Abu-Assab states: 'Sexually, culturally, and physically women are boundary markers for ethnic groups, and speaking of gender relations in "other" ethnic groups or communities is frequently used as a marker of difference. Gender relations often served to set group boundaries' (Abu-Assab: 2012). However, in this context I am not talking about ethnicity but rather about socioeconomic differences between camp refugees and others. As a woman interviewee stated: 'We have very different life-styles, very different. They have [a] very different moral standing, we are more authentic in our lifestyles, women do not dress modestly outside' (AlWihdat refugee camp, 2008).

The situation of refugee camps in Jordan has a significant influence on women's experiences. Such conditions make the application of gender bias and patriarchy much more negative on women and girls' lives. Interestingly, place of residence influences women's experiences, as refugee camps are not considered 'safe' areas and consequently would influence women's mobility and freedom of movement. It has become apparent that safety is very much linked to poverty in refugee camps. Female interviewees mentioned that there are high crime levels because of poverty, which can lead to women feeling 'unsafe' and can constitute a real physical danger. 'Unsafe' conditions in the camps can lead men to controlling women's sexuality by preventing them to move freely.

Distance from schools was a recurring theme, which explained why some women had less access to education. Women from refugee camps had to leave school at an early age because of the lack of secondary schools in the area where they live. Distance from a school was an issue that women's families regarded as an issue of 'safety' and 'protection'. This shows that women's access to education is limited by the social control exercised by the male heads of household. Women explained how their families had in some cases forced them into marriage and in other cases arranged for them to be married because they could not afford to send them to distant schools. My research data shows that poverty and camp situations reinforced patriarchal structures, as women got married at early ages.

Enloe states that women always carry the burden of the community instead of the men; men ascribe symbolic roles to women, which can be 
manifested in different ways and affect women's experiences and lives. Women are seen as: "1) the community's-or the nation's most valuable possession, 2) the principle vehicles for transmitting the whole nation's values from one generation to the next, 3 ) bearers of the community's future generations- crudely, nationalist wombs, 4) the members of the community most vulnerable to defilement and exploitation by oppressive alien rulers, and 5) most susceptible to assimilation and co-option by insidious outsiders"' (Enloe, 1989: 54).

\section{Conclusion}

Sixty-seven years on, the Palestinian refugee issue has not and should not be forgotten. Palestinians have been at the crossroads, either in occupied Palestine and/or hosting countries. Palestinian refugees and internally displaced Palestinians are always situated at the intersection of any political, social and economic changes in the Arab Middle East. For millions of Palestinian refugees, extreme poverty is only one aspect of their struggle. Their precarious socio-political position contributes to their feelings of instability and lack of political security in host countries. Thus many still suffer the legacy of their dispossession: destitution, impoverishment and insecurity. This article took a feminist approach to understanding the experiences of women refugees; an approach that allows this marginalised group of refugees a voice.

A feminist approach scrutinises the position of women in nationalist movements and also refugee women, and demonstrates that their experiences are different from their male counterparts. I argue that women are assigned symbolic roles that are manifested in materialistic ways. Those symbolic roles include women being the 'bearers' of the nation and the reproducers. Those narratives undermine women's experiences as individuals and make them part of the collective, thus overlooking the oppression they face because of their gender. It has become apparent that women refugees in camps face different experiences in comparison to those of men, as there are more restrictions on them and their mobility is controlled.

Recent events in the Arab World, such as the situation in Syria, in addition to the discriminatory laws in Lebanon, have lately disproportionately affected Palestinian refugees, as they never enjoyed full citizenship in host countries. Most of the narrative surrounding the experiences of refugees focuses heavily on nationalist sentiments, their 'right to return', as well as their political, social and economic marginalisation. In this article, I have demonstrated that the 'issue' of Palestinian refugees should not be exclusive to men's experiences, and it 
should include women. A gendered examination should always be integrated into a study of refugee experience to produce a more comprehensive analysis. I argue that the situation of refugees is very much gendered as refugee women face different experiences than those of men under those circumstances. On the basis of my discussion in this article, it is clear that more research should be carried out to critically assess and analyse the situation of refugees in general and women in particular. It is also important to highlight that despite the fact that their flight took place sixty-seven years ago, their situation remains very different, depending on the political environment in which they settled and remain at the mercy of their host countries. Policy makers must address the needs of this vulnerable group, and bring more permanent and sustainable solutions to their problems to the table.

\section{References}

Abdo, N. (1990), 'Nationalism and Feminism: Palestinian Women and the Intifada', in Moghadam, V.M. (ed.) Gender and National Identity: Women and Politics in Muslim Societies, London: Zed Books, 148-170

Abu-Assab, N. (2012), 'Narratives of Ethnicity and Nationalism: A Case Study of Circassians in Jordan', unpublished PhD thesis, University of Warwick, UK

Akram, S. M. (2002), 'Palestinian Refugees and Their Legal Status: Rights, Politics, and Implications for a Just Solution', Journal of Palestine Studies, $31,36-51$

Amawi, A. (2000), 'Gender and Citizenship in Jordan', in Joseph, S. (ed.) Gender and Citizenship in the Middle East, New York: Syracuse University Press

Abu Murad, T. A. (2004), 'Palestinian Refugee Conditions Associated with Intestinal Parasites and Diarrhoea: Nuseirat Refugee Camp as a Case Study', Public Health, 118, 131-42

Ehrlich, A. (2004), 'On the Right of Return, Demography and EthnicCleansing in the Present Phase of the Israeli-Palestinian Conflict', Orient Deutsche Zeitschrift fur Politik und Wirtschaft des Orients, 45, 549-563

El Abed, O. (2009), Unprotected: Palestinians in Egypt since 1948, Canada: IDRC

El Abed, O. (2006), 'Immobile Palestinians: ongoing plight of Gazans in Jordan', Forced Migration Review 26, 17-18 
El Abed, O. (2004), 'The forgotten Palestinians: how Palestinian refugees survive in Egypt', Forced migration review, 20, 29-31

El Sayed- Ali, S. (2006), 'Palestinian Refugees in Lebanon', Forced Migration Review, 26, 13-14

El-Solh, C. F. (2003), 'Gender, Poverty and Employment in the Arab Region', Geneva, Capacity-Building Program on Gender Poverty and Employment \& National Policy Group

Enloe, C. (1989), Bananas, Beaches and Bases: Making Feminist Sense of International Politics, London: Pandora Press

Joseph, S. (1993), 'Gender and Relationality Among Arab Families in Lebanon', Feminist Studies, 19, 465-86

Joseph, S. (1996), 'Patriarchy and Development in the Arab World', Gender and Development, 4, 14-19

Hanafi, S. (2011) 'Governing the Palestinian Refugee Camps in Lebanon and Syria: The Case of Nahr el-Bared and Yarmuk Camps', in Knudsen, A. \& Hanafi, S. (eds) Palestinian Refugees: Identity, Space and Place in the Levant, USA: Routledge, 14-29

Kandiyoti, D. (1988), 'Bargaining with Patriarchy', Gender and Society, 2, 274-90

Khalidi, W. ed. (1992), All That Remains: The Palestinian Villages Occupied and Depopulated by Israel in 1948, Washington, D.C.: Institute for Palestine Studies

Khalidi, W. (2005) 'Why Did the Palestinians Leave, Revisited', Journal of Palestine Studies, 34, 42-54

Khawaja, M. (2003), 'Migration and the Reproduction of Poverty: The Refugee Camps in Jordan', International Migration, 41, 27-57

Klein, R. D. (1983), 'How to do what we want to do: Thoughts about feminist methodology', in Bowles, G. \& Klein, R. D. (eds.) Theories of Women's Studies, London: Routledge and Kegan Paul

Masalha, N. (1992), Expulsion of the Palestinians: The Concept of "Transfer" in Zionist Political Thought, 1882-1948, Washington, D.C.: Institute for Palestine Studies

Massad, J. A. (2001), Colonial Effects: The Making of National Identity in Jordan, New York: Columbia University Press

Moghadam, V. M. (1993), Modernising Women: Gender and Social Change in the Middle East, Colorado: Lynne Rienner 
Reinharz, S. (1992), Feminist Methods in Social Research, Oxford: Oxford University Press

Reinharz, S. (1997), 'Who Am I? The Need for a Variety of Selves in the Field', in Hertz, R. (ed.) Reflexivity and Voice, London: Sage Publications

Roseneil, S. (1993) 'Greenham Revisited: Researching Myself and my Sisters', in Hobbs, D. \& May, T. (eds.) Interpreting the Field: Accounts of Ethnography, Oxford: Oxford University Press

Q \& A: 'What you need to know about Palestinian Refugees and Internally Displaced Persons, 2015'. Badil: Resource Centre for Palestinian Residency and Refugee Rights:

http://www.badil.org/en/press-releases/149-2015/4451-pren19051515 [accessed 16/06/2015]

Said, E. (2001), 'Introduction: The Right of Return at Last', in N. Aruri (ed.), Palestinian Refugees: The Right of Return, Pluto Press, London, 135

Shalhoub-Kevorkian, N. (2010), 'Palestinian Women and the Politics of Invisibility: Towards a Feminist Methodology', Peace Prints: South Asian Journal of Peace building, 3(1): http://madaresearch.org/en/2013/07/28/palestinian-women-and-the-politics-ofinvisibility-towards-a-feminist-methodology-nadera-shalhoub-kevorkian2/ [accessed 30/10/2015]

Shiblak, A. (1996), 'Residency status and civil rights of Palestinian refugees in Arab countries', Journal of Palestine Studies, 25(3), 36-45

Shiblak, A. (2006), 'Stateless Palestinians', Forced Migration Review, 26, 8-9: http://www.fmreview.org/FMRpdfs/FMR26/FMR2603.pdf [accessed 30/10/2015]

Stanley, L. \& Wise, S. (1990), 'Method, Methodology and Epistemology in Feminist Research Processes', in Stanley, L. (ed.) Feminist Praxis: Research, Theory and Epistemology in Feminist Sociology, London: Routledge

Stanley, L. \& Wise, S. (1993) Breaking Out Again: Feminist Ontology and Epistemology London, London: Routledge

Zureik, E. (2002), 'The Palestinian Refugee Problem: Conflicting Interpretations', Global Dialogue, 4(3): http://www.worlddialogue.org/content.php?id=237 [accessed 30/10/2015] 
To cite this article:

Nasser Eddin, N. (2015). 'Palestinian Refugees: A Gendered Perspective'. Exchanges: The Warwick Research Journal, 3(1), 95-112. Retrieved from: http://exchanges.warwick.ac.uk/index.php/exchanges/article/view/66 